\title{
Identifikasi Potensi Modus Kegagalan yang Dapat Menghambat Kelancaran Proses Pelayanan Rawat Jalan Menggunakan Failure Mode Effect Analysis (FMEA) di Rumah Sakit BM Jakarta Barat
}

\author{
Achmaddudin Sudiro* \\ *Program Studi Administrasi Rumah Sakit Sekolah Tinggi Indonesia Maju \\ Email:achmaddudinsudiro2@gmail.com
}

\begin{abstract}
Outpatient services visitor in hospital keep increasing in every year. To provide the high quality services and maintain patient satisfaction, it is needed to identify the possible problems that might occur in the outpatient services and conduct a prevention strategy. This research aimed to identify potential failure mode that can menghambat services in the outpatient care unit using the Failure Mode Effect Analysis (FMEA) method. This was qualitative research using an observation survey approach and in-depth interviews with the outpatient service head coordinator. Research conducted in February 2020. The results of this research indicate that potential failure mode which has RPN value above the cut off point 180 were six out of ten failure modes, such as the examination is not on schedule (360), the patient lags a turn call order Check (270), third, Specific drug failure is not available (245), general patient protests with the price of the drug (224), the patient is void to poly (196), patient registrant online missed sequence number queue (180). Based on the results of the research, hospitals are expected to follow up with the results of this research by conducting a redesign of the process that occurs today using the FMEA to maintain service quality.
\end{abstract}

Keywords: Outpatient, Risk Management, FMEA

\section{PENDAHULUAN}

Rumah sakit adalah institusi pelayanan kesehatan yang menyelenggarakan pelayanan kesehatan perorangan secara paripurna yang menyediakan pelayanan rawat inap, rawat jalan, dan gawat. ${ }^{1}$ Pelayanan rawat jalan yang diselenggarakan oleh rumah sakit tidak pernah absen dari kunjungan masyarakat. Baik untuk melakukan konsultasi maupun melakukan pengobatan.

Berdasarkan data Kementrian Kesehatan per 9 Januari 2019 tercatat total rumah sakit (Fasilitas Kesehatan Tingkat Lanjut) di Indonesia sebanyak 2.813. ${ }^{2}$ Sedangkan berdasarkan laporan tahunan BPJS per 31 desember 2018 tercatat total rumah sakit yang bekerjasama dengan BPJS sebanyak 2.455, dan peserta jaminan kesehatan nasional yang melakukan kunjungan ke poliklinik rawat jalan rumah sakit mencapai angka 76,8 juta peserta. ${ }^{3}$ Jumlah ini mengalami peningkatan dari tahun-tahun sebelumnya.

Dengan tren pengunjung rawat jalan yang selalu meningkat ini secara alamiah memaksa rumah sakit untuk terus melakukan upaya proaktif dalam rangka merespon tren peningkatan pengunjung 
rawat jalan ini. sehingga proses penyelenggaraan kesehatan dapat terus berjalan dengan tetap mempertahankan setiap dimensi mutu pelayanan dan sesuai dengan Standar Minimun Pelayanan Rumah Sakit. ${ }^{4}$ Ketidaksiapan rumah sakit dalam merespon tren peningkatan ini akan mempengaruhi kualitas pelayanan rumah sakit sehingga berdampak pada loyalitas pasien. Kualitas pelayanan dan kepuasan pasien mempunyai pengaruh terhadap loyalitas pasien sebesar $58,6 \% .^{5}$

Rumah Sakit BM merupakan rumah sakit swasta kelas C dengan status akreditasi Tingkat Pertama yang terletak di Jakarta barat sudah bekerjasama dengan BPJS dalam melakukan pelayanan kesehatan. Berdasarkan hasil wawancara dengan kepala koordinator pelayanan rawat rawat jalan mengatakan setiap harinya rata-rata pasien yang melakukan kunjungan di pelayanan rawat jalan mencapai 800-900 pengunjung dengan rata-rata peserta BPJS.

Penelitian ini bermaksud untuk mengidentifikasi potensi kegagalan yang dapat menghambat kelancaran pada setiap alur proses pelayanan rawat jalan di Rumah Sakit BM menggunakan metode Failure Mode Effect Analysis (FMEA) sebagai upaya penilaian risiko untuk mengidentifikasi potensi kerentanan dalam kompleksitas dan proses yang memiliki risiko tinggi dan untuk membuat tindakan perbaikan sebelum terjadinya kejadian yang merugikan. ${ }^{6}$

\section{METODE PENELITIAN}

Rancangan penelitian kualitatif menggunakan pendekatan survei observasi dan wawancara kepala koordinator pelayanan rawat jalan dilakukan pada bulan Februari 2020 pada alur proses pelayanan unit rawat jalan Rumah Sakit BM.

Teknik Analisis pada penelitian ini menggunakan metode Failure Mode Effect Analysis (FMEA) untuk mengetahui potensi risiko yang dapat menghambat kelancaran alur proses pelayanan di unit rawat jalan.

Tahapan proses penelitian ini terlebih dahulu mengindentifikasi alur proses yang sedang berjalan. Setelah itu dilakukan penentuan potensi kegagalan yang berpotensi terjadi. Setelah dilakukan penentuan potensi kegagalan selanjutnya mengetahui Risk Priority Number (RPN) dengan cara nilai occurrence dikali dengan nilai severity dan kemudian dikalikan dengan nilai detection. Jika nilai RPN sudah diketahui, selanjutkan nilai cut off pont yang ditentukan berdasarkan prinsip pareto digunakan untuk menentukan prioritas modus kegagalan pada titik alur proses mana yang harus dilakukan tindak lanjut dan penanganan dengan segera.

\section{HASIL DAN PEMBAHASAN}

Identifikasi alur proses pelayanan rawat jalan serta menentukan potensi modus kegagalan (failure mode) yang mungkin terjadi, potensi penyebab dari modus kegagalan, serta potensi dampak yang ditimbulkan, mengacu pada alur proses (workflow) pelayanan rawat jalan di Rumah Sakit BM saat ini. 


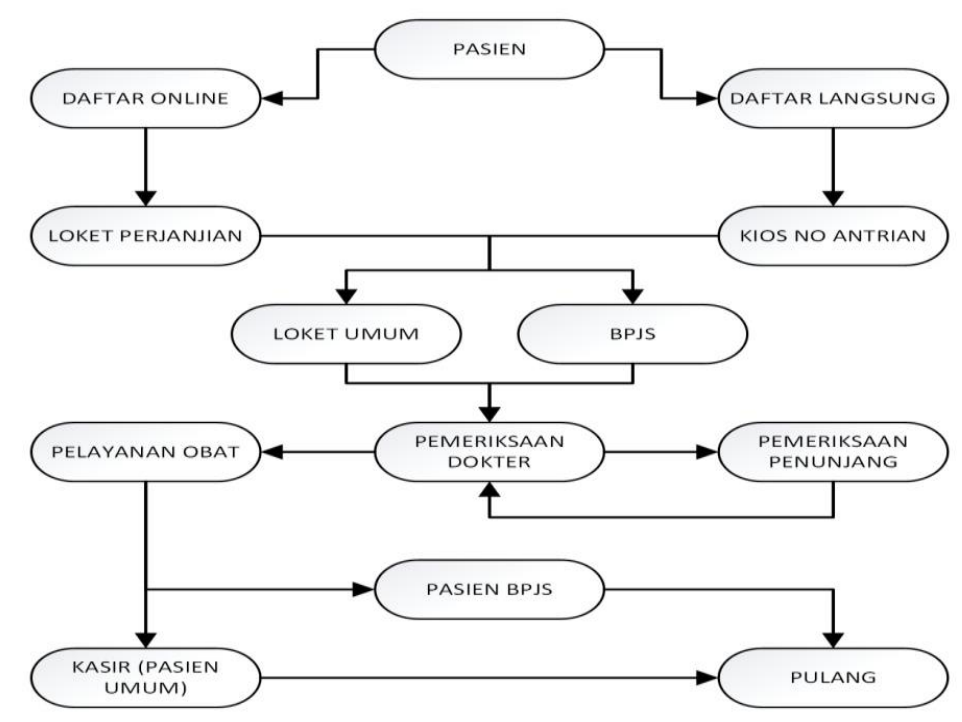

\section{Gambar 1. Alur Proses Pelayanan Rawat Jalan Rumah Sakit BM}

\section{Proses pertama (cara satu) pendaftaran no antri online}

Pasien atau keluarga pasien melakukan pendaftaran melalui salah satu cara pendaftaran online 1) Melalui pihak ketiga Alodok, 2) Melalui nomor Whatsapp RS, 3) Melalui Telepon Call Centre, 4) Melalui Website RS. Berkas yang diminta pada saat melakukan pendaftarkan diri melalui salah satu cara ditersebut, pasien BPJS cukup melampirkan nomor KTP dan Nomor Kepesertaan BPJS. Jika pasien umum cukup melampirkan nomor KTP dan nomor KK sebagai tambahan.

Waktu yang dihabiskan untuk melakukan pendaftaran no antrian secara mendiri membutuhkan waktu kurang lebih tiga sampai lima menit. Pada tahap ini, potensi kegagalan yang mungkin terjadi adalah: 1) terjadinya kelumpuhan sistem (system down).

Potensi Penyebab dari potensi kegagalan sistem down adalah jika adanya lonjatan visitor/user dari banyaknya pintu sedangka tidak ditampung server dengan baik. Potensi dampak dari ini adalah: 1) Loading system page yang lambat, 2) Proses olah data terganggu.

Penggunaan system pendaftaran online sudah tepat diterapkan di Rumah Sakit BM, Rumah Sakit BM yang sudah menggunakan SIMRS dan memanfaatkan teknologi yang ada sebagai langkah untuk memberikan kemudahan kepada pasien yang hendak melakukan kunjungan di rawat jalan. Hasil penelitian menunjukan persepsi pasien yang tidak tidak suka dengan metode tradisional di meja pendaftaran mencapai $59 \%{ }^{7}$

Dengan pemanfaatan teknologi ini memberikan dampak positif terhadap kelancaran proses pendaftaran antrian. Mesipun demikian, teknologi penggunaan teknologi juga tidak lepas dari kekurangan yang perlu diperhatikan dari sisi keamanan, fleksibilitas, privasi, dan kompleksitasnya. ${ }^{8}$

Meskipun demikian, SIMRS yang digunakan rumah sakit tidak menutup kemungkinan adanya kelumpuhan sistem. Sehingga memerlukan pengendalian dan pencegahan terkait kemungkinan kelumpuhan tersebut.

Proses pertama (cara dua) ambil nomor antrian langsung

Pasien datang ke rumah sakit, kemudian mengambil langsung nomor antrian berdasarkan kepesertaan (BPJS/Umum) di mesin pengambilan nomor antrian. Mesin tersebut yang ditaruh di tengah ruang tunggu samping koridor masuk menuju counter registrasi. Pasien atau keluarga pasien sendiri 
menekan salah satu tombol yang bertuliskan [UMUM] dan [BPJS]. Tidak ada berkas atau lampiran yang perlu diserahkan untuk mengambil nomor antrian di mesin pengambilan nomor antrian.

Waktu yang digunakan saat mengambil nomor antrian membutuhkan urang lebih 7 sampai 15 detik per pasien. Pada tahap ini, potensi kegagalan yang mungkin terjadi adalah kehabisan kertas dan tinta serta mesin dimainkan oleh orang iseng.

Potensi Penyebab dari potensi kegagalan kehabisan kertas dan tinta adalah tidak ada pengecekan tinta dan kertas secara rutin. Potensi dampak dari ini adalah:

1. Lembar nomor antrian tidak keluar

2. Sistem pengambilan no antrian menjadi manual.

Potensi Penyebab dari potensi kegagalan Mesin dimainkan oleh orang iseng adalah jika mesin mudah dimainkan. Potensi dampak dari ini adalah:

1. Pemborosan tinta dan kertas

2. Petugas memanggil nomor antrian tanpa pasien

3. Membuang tenaga petugas

4. Memperlambat proses pelayanan.

Mesin antrian sudah banyak digunakan oleh banyak pihak, hal ini tidak lepas dari kemanfaatan yang didapat dari penggunaan mesin antrian untuk pelayanan rawat jalan. Salah satunya hasil penelitian Nengsih MK, dkk menunjukan waktu terpanjang yang diperlukan pasien dalam system adalah 1,111 menit yang terjadi pada jam 09.00-10.00 dan 10.0011.00 dan waktu terpendek adalah 0,059 menit yang terjadi pada jam 11.00-12.00. ${ }^{9}$

\section{Proses kedua di counter registrasi}

Setelah mendapat nomor antrian dari mesin tersebut, Pasien menunggu mendapat panggilan untuk tahap registrasi di salah satu counter registrasi dari sembilan counter registrasi, tergantung jenis poli yang dituju. Setelah pasien melakukan pendaftaran di counter registrasi, berkas tersebut diserahan ke ruang perawat untuk dilakukan pengecapan dan pelabelan.

Di loket registrasi, jika pasien tersebut merupakan pasien BPJS maka pasien menunjukan kebenaran nomor antrian dan membawa berkas Surat Rujukan, fotocopy KTP dan BPJS. Jika pasien umum, maka pasien membawa berkas fotocopy KTP dan KK. Di counter registrasi,

Pasien atau keluarga pasien melakukan pendaftaran membutuhkan waktu 5 sampai 7 menit. Pada tahap ini, potensi kegagalan yang mungkin terjadi adalah: 1) Pasien pendaftar online terlewat urutan nomor antrian, 2) Ketidak tepatan Poli tertuju oleh rujukan Faskes tingkat pertama, 3) Pasien batal ke poli.

Potensi Penyebab dari potensi kegagalan pasien pendaftar online terlewat urutan nomor antrian adalah jika tidak ada keterangan waktu urutan. Potensi dampak dari ini adalah: 1) Pasien belum tiba di RS saat di panggil / telat, 2) Pemanggilan berulang memperpanjang waktu proses pelayanan

Berdasarkan hasil observasi pelayanan rawat jalan di Rumah Sakit BM menunjukan bahwa setiap counter registrasi menangani pendaftaran pasien untuk poli yang berbeda memberikan dampak positif terhadap kelancaran poses pelayanan. Seperti hasil penelitian yang menunjukan banyaknya counter pendaftaran berdampak positif terhadap waktu proses pelayanan. ${ }^{10}$ Ketepatan waktu pelayanan memiliki pengaruh juga terhadap kepuasan pasien. ${ }^{11}$

Potensi Penyebab dari potensi kegagalan ketidak tepatan Poli tertuju oleh rujukan fasilitas kesehatan tingkat pertama adalah jika faskes tingkat pertama tidak mengetahui poli tertuju. Potensi dampak dari ini adalah: 1) Pasien mengulan antrian

Sedangkan pelaksanaan system rujukan Rumah Sakit BM sudah berjalan sudah sesuai dengan Peraturan Menteri 
Kesehatan No.1 Tahun 2012 Tentang Sistem Rujukan Perorangan. Namun, masih adanya kendala dari sisi pasien untuk membawa surat rujukan. Hal ini tentu menjadi salah satu faktor penghambat kelancara proses pelayanan pasien BPJS itu sendiri. ${ }^{12}$

Potensi Penyebab dari potensi kegagalan pasien batal ke poli adalah jika Pasien BPJS tidak membawa surat rujukan faskes tingkat pertama. Potensi dampak dari ini adalah: 1) Penurunan jumlah pasien berobat, 2) Persepsi buruk oleh pasien yang tidak mengerti.

\section{Proses ketiga saat pemeriksaan dokter}

Pasien masuk ke poli dan dilakukan pemeriksaan dan tindakan oleh dokter. Assessment oleh dokter menghabiskan waktu yang berbeda disetiap jenis poli dan antara pasien satu dengan yang lain. Pada tahap ini, potensi kegagalan yang mungkin terjadi adalah: 1) Pemeriksaan tidak sesuai jadwal, 2) Pasien tertinggal panggilan giliran urutan periksa.

Potensi Penyebab dari potensi kegagalan pemeriksaan tidak sesuai jadwal adalah jika dokter telat datang. Potensi dampak dari ini adalah: Penumpukan pasien menunggu.

Potensi Penyebab dari potensi kegagalan pasien tertinggal panggilan giliran urutan periksa adalah jika pasien tidak berada di RS saat gilirannya tiba. Potensi dampak dari ini adalah: Pemanggilan berulang, memperpanjang waktu proses pelayanan.

Hasil penelitian Azwar VY, dkk menunjukan adanya pengaruh keterlambatan dokter di poli terhadap kepuasan pasien. ${ }^{13}$ Selaras dengan hasil penelitian David D, dkk menunjukan hubungan yang kuat antara kepuasan pasien dengan ketepatan jam kedatangan dokter di ruang rawat jalan. ${ }^{14}$ Oleh karena itu, semakin lamanya nya waktu tunggu pasien rawat jalan akan meningkatkan meningkat pula presentasi ketidak puasan pasein terhadap pelayanan. ${ }^{15}$
Berdasarkan kode etik dokter disebutkan bahwa Seorang dokter wajib, dalam setiap praktik medisnya, memberikan pelayanan secara kompeten dengan kebebasan teknis dan moral sepenuhnya, disertai rasa kasih sayang (compassion) dan penghormatan atas martabat manusia. ${ }^{13}$

Selain itu, sebaggai professional pemberi asuha (PPA) dituntun untuk memperharikan seluruh dimensi mutu pelayanan yang termasuk didalamnya pelayanan focus pasien (patient-centered care). Oleh karennya, keterlambatan dokter sangat berpengaruh terhadap kualitas pelayanan

\section{Proses keempat di pelayanan obat di apotek}

Pasien atau keluarga pasien menyerahkan resep obat kepada petugas di Apotek RS. Bagi Pasien umum akan dikenakan biaya sesuai dengan harga yang tertera pada kwitansi. Setelah membayar sejumlah yang diinformasikan, obat diserahan ke pasien disertai informasi obat. Adapun berkas yang diminta. Bagi pasien BPJS, pasien meyertakan kelengkapan keabsahan resep (SEP, nama dokter, tanggal penulisan resep). Bagi pasien umum membawa resep dokter. Setelah diserahkan, pasien menunggu petugas menyerahkan obat diserahan ke pasien disertai informasi obat. Pelayanan obat di apotek oleh petugas untuk menyelesaikan pengemasan obat membutuhkan waktu rata-rata sekitar 15 menit. Untuk resep obat yang terdapat racikan membutuhkan waktu 25 sampai 30 menit. Pada tahap ini, potensi kegagalan yang mungkin terjadi adalah 1) Pasien umum protes dengan harga obat.

Potensi Penyebab dari potensi kegagalan Pasien umum protes dengan harga obat adalah jika oleh pasien dirasa terlalu malah. Potensi dampak dari ini adalah: 1) Persepsi buruk dari pasien.

Potensi Penyebab dari potensi kegagalan obat tertentu tidak tersedia adalah jika tidak ada pengadaan obat yang 
diresepkan. Potensi dampak dari ini adalah: 1) Pembelian obat pasien di luar apotek rumah sakit

Berdasarkan hasil wawancara mendalam dengan kepala koordinasi pelayanan rawat jalan rumah sakit BM menyatakan bahwa masih adanya kemungkinan pasien yang mempermasalahkan harga obat meski jumlahnya tidak banyak.

Hal serupa dengan hasil penelitian Gloud, dkk menyatakan bahwa orang yang sengaja membeli obat di apotek secara langsung, sedikit yang mempermasalahkan harga obat. Untuk meningkatkan kepuasan pasien dalam pengalamannya di apotek rumah sakit. ${ }^{17}$
Selain itu, kelengkapan obat nonformularium nasional harus diperhatikan oleh rumah sakit, hal ini karena juga adanya hubungan antara kelengkapan obat dengan kepuasan pasien. ${ }^{14}$

\section{Menentukan Risk Priority Number (RPN)}

RPN ditentukan dengan mengkalikan tiga faktor (Occurrence X Severity X Detection) dan urutan pringkat prioritas modus kegagalan (failure mode) diketahui. ${ }^{18}$ Nilai Cut off point ditentukan menggunakan prinsip pareto dengan menghitung presentase kumulatif 80 persen adalah 180. Selanjutnya modus kegagalan yang nilainya diatas cut off point diprioritaskan untuk ditindaklanjuti.

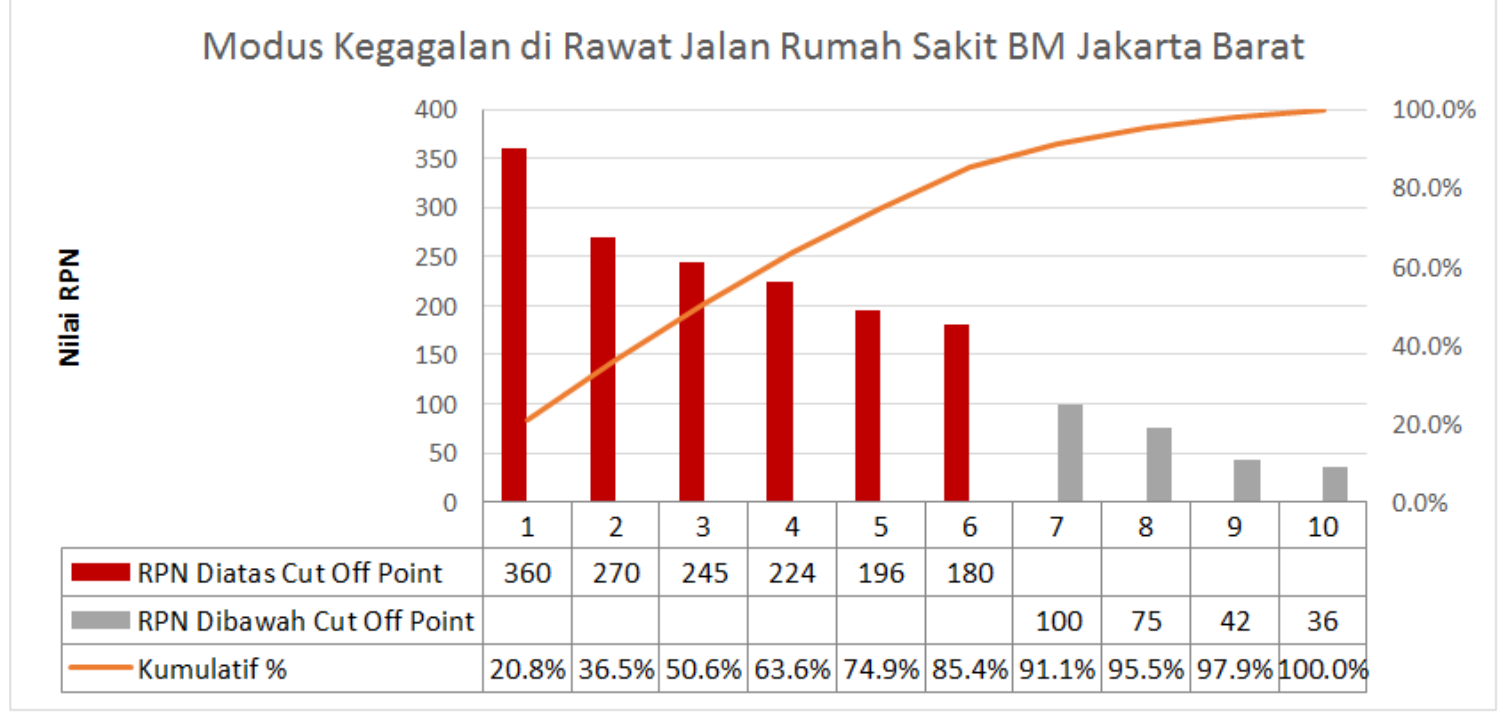

Gambar 2. Presentase Modus kegagalan di rawat jalan Rumah Sakit MB

Pada Gambar 2. diatas menunjukan ada enam modus kegagalan yang menjadi penghambat kelancaran proses pelayanan rawat jalan di Rumah Sakit BM yaitu 1) Potensi Modus kegagalan Pemeriksaan tidak sesuai jadwal yang disebabkan karena potensi Dokter telat datang dengan nilai RPN sebesar 360, 2) Potensi Modus kegagalan Pasien tertinggal panggilan giliran urutan periksa yang disebabkan karena potensi Pasien tidak berada di RS saat gilirannya tiba dengan nilai RPN sebesar 270, 3) Potensi Modus kegagalan Obat tertentu tidak tersedia yang disebabkan karena potensi Tidak ada pengadaan obat yang diresepkan dengan nilai RPN sebesar 245, 4) Potensi Modus kegagalan Pasien umum protes dengan harga obat yang disebabkan karena potensi Oleh pasien dirasa terlalu mahal dengan nilai RPN sebesar 224, 5) Potensi Modus kegagalan Pasien batal ke poli yang disebabkan karena potensi Pasien BPJS tidak membawa surat rujukan faskes tingkat dengan nilai RPN sebesar 196, 6) Potensi Modus kegagalan Pasien pendaftar online terlewat urutan nomor antrian yang disebabkan karena potensi Tidak ada keterangan waktu urutan dengan nilai RPN sebesar 180. 
Sedangkan nilai RPN pada empat modus kegagalan lainnya masih dibawah cut off point dan masih bias ditolelir yaitu 1) Modus kegagalan Mesin dimainkan oleh orang iseng yang disebabkan karena potensi Mesin mudah dimainkan dengan nilai RPN sebesar 100, 2) Potensi Modus kegagalan Sistem RS down yang disebabkan karena potensi Lonjatan visitor/user dari banyak pintu dan tidak ditampung server dengan baik dengan nilai RPN sebesar 75, 3) Potensi Modus kegagalan Ketidak tepatan Poli tertuju oleh rujukan Faskes tingkat pertama yang disebabkan karena potensi Faskes tingkat pertama tidak mengetahui poli tertuju dengan nilai RPN sebesar 42, 4) Potensi Modus kegagalan Kehabisan kertas dan tinta yang disebabkan karena potensi Tidak ada pengecekan rutin tinta dan kertas dengan nilai RPN sebesar 36 .

Selanjutnya, Rumah Sakit BM diharapkan melakukan tindaklanjut terhadap setiap potensi modus kegagalan hasil penilaian diatas sebagai upaya pencegahan terhadap potensi kegagalan yang ada mungkin terjadi. Rumah sakit dapat melakukan investigasi lebih lanjut meggunakan metode FMEA dan melakukan redesign terhadap alur proses yang berjalan saat ini. Agar proses pelayanan rawat jalan di Rumah Sakit BM dapat berjalan berdasarkan mutu pelayanan dan standar pelayanan minimum rumah sakit yang berlaku.

\section{KESIMPULAN}

Metode FMEA dapat memberikan gambaran yang jelas terhadap potensi kegagalan yang dapat menghambata proses alur pelayaan rawat jalan di rumah sakit BM. Sehingga potensi tersebut dapat ditindaklanjuti sebagai upaya sebelum potensi kegagalan tersebut terjadi.

Potensi kegagalan yang memiliki nilai RPN diatas cut off point sebesar 180 merupakan potensi kegagalan yang dapat menghambat proses kelancaran proses pelayanan rawat jalan di Rumah Sakit BM. Enam dari sepuluh potensi kegagalan diantaranya menyandang nilai RPN diatas cut off point.

Pertama, potensi modus kegagalan Pemeriksaan tidak sesuai jadwal. Kedua, potensi modus kegagalan Pasien tertinggal panggilan giliran urutan periksa. Ketiga, potensi modus kegagalan obat tertentu tidak tersedia. Keempat, potensi modus kegagalan Pasien umum protes dengan harga obat. Kelima, potensi modus kegagalan Pasien batal ke poli. Keenam, potensi modus kegagalan pasien pendaftar online terlewat urutan nomor antrian.

Saran yang dapat disampaikan dari hasil penelitian ini agar mutu pelayanan dapat dipertahankan adalah dengan melakukan pengkajian mendalam setiap potensi modus kegagalan yang mungkin terjadi di pelayanan rawat jalan menggunakan FMEA dan melakukukan redesign terhadap alur proses yang berlaku saat ini.

\section{UCAPAN TERIMA KASIH}

Penulis mengucapkan terima kasih kepada Rumah Sakit BM atas ijin yang diberikan untuk melaksanakan penelitian ini. Penulis juga mengucapkan terima kasih kepada seluruh responden yang bersedia berpartisipasi pada penelitian ini.

\section{DAFTAR PUSTAKA}

1. Undang-Undang RI Nomor 44 Tahun 2009. Tentang Rumah Sakit. Jakarta; 2018.

2. Kementrian Kesehatan RI. Data dan Informasi Profil Kesehatan Indonesia 2018. Jakarta; 2019.

3. BPJS Kesehatan. Laporan Pengelolaan Program Tahunan 2018 \& Laporan Keuangan Tahun 2018 (Auditan). BPJS Kesehatan; 2019.

4. Keputusan Menteri Kesehatan. Standar Pelayanan Minimum Rumah Sakit. Kementrian Kesehatan RI; 2018.

5. Puti WC. Pengaruh kualitas pelayanan dan kepuasan terhadap loyalitas 
pasien rawat jalan dan rawat inap rumah sakit otorita batam. 2013;

6. Ashley L, Armitage G, Neary M, Hollingsworth G. A Practical Guide to Failure Mode and Effects Analysis in Health Care: Making the Most of the Team and Its Meetings. Agustus 2010 [dikutip 2 Maret 2020];36. Tersedia pada: https://linkinghub.elsevier.com/retriev e/pii/S1553725010360533

7. Justinia T. Patients Online Registration System: Feasibility and Perceptions. Ann Med Health Sci Res. 2017;7(3):6.

8. Peng S-L, Pal S, Huang L, editor. Principles of Internet of Things (IoT) Ecosystem: Insight Paradigm [Internet]. Cham: Springer International Publishing; 2020 [dikutip 3 Maret 2020]. (Intelligent Systems Reference Library; vol. 174). Tersedia pada: http://link.springer.com/10.1007/9783-030-33596-0

9. Nengsih MK, Yustanti MV. Analisis Sistem Antrian Pelayanan Administrasi Pasien Rawat Jalan Pada Rumah Sakit Padmalalita Muntilan. Manag Insight J Ilm Manaj [Internet]. 28 Juni 2019 [dikutip 2 Maret 2020];12(1):68-78. Tersedia pada: https://ejournal.unib.ac.id/index.php/I nsight/article/view/7752

10. Itaar A, Aryanny E, Purnamawati E. Penentuan Jumlah Loket Pelayanan Yang Optimal Di Bpjs Kesehatan Cabang Sidoarjo. Tekmapro J Ind Eng Manag. 2018;13(1):1-13.

11. Adamu H. Patient Satisfaction with Services at a General Outpatient Clinic of a Tertiary Hospital in Nigeria. $\mathrm{Br} J$ Med Med Res [Internet]. 10 Januari 2014 [dikutip 3 Maret
2020];4(11):2181-202. Tersedia pada: http://www.sciencedomain.org/abstrac t.php?iid=411\&id=12\&aid=3427

12. Hutauruk PM, Gurning MMB. Faktor-Faktor Penghambat Pelayanan Di Tempat Pendaftaran Pasien Bpjs Rawat Jalan Di Rumah Sakit Sari Mutiara, Lubuk Pakam Tahun 2019. J Ilm Perekam Dan Inf Kesehat Imelda. 2019;4(2):668-74.

13. Azwar VY, Putra AS. Analisis faktor kualitas pelayananterhadap kepuasan pasien rawat jalan rsud dr. Achmad darwis. 20017;8.

14. David D, Hariyanti T, Widayanti Lestari E. Hubungan Keterlambatan Kedatangan Dokter terhadap Kepuasan Pasien di Instalasi Rawat Jalan. J Kedokt Brawijaya [Internet]. 3 Agustus 2014 [dikutip 2 Maret 2020];28(1):31-5. Tersedia pada: http://jkb.ub.ac.id/index.php/jkb/articl e/view/518

15. Laeliyah N, Subekti H. Waktu Tunggu Pelayanan Rawat Jalan dengan Kepuasan Pasien Terhadap Pelayanan di Rawat Jalan RSUD Kabupaten Indramayu. $J$ Kesehat Vokasional [Internet]. 17 Agustus 2017 [dikutip 2 Maret 2020];1(2):102. Tersedia pada: https://jurnal.ugm.ac.id/jkesvo/article/ view/27576

16. Pengurus Besar Ikatan Dokter Indonesia. Kode Etik Dokter. Jakarta; 2012.

17. Gould O, Buckley P, Doucette D. What Patients Want: Preferences Regarding Hospital Pharmacy Services. Can J Hosp Pharm [Internet]. 28 Juni 2013 [dikutip 3 Maret 2020];66(3). Tersedia pada: http://www.cjhp- 
online.ca/index.php/cjhp/article/view/ 1255

18. Harianto H, Khasanah N, Supardi S. Kepuasan Pasien Terhadap Pelayanan Resep Di Apotek Kopkar Rumah Sakit Budhi Asih Jakarta. Pharm Sci Res [Internet]. April 2005 [dikutip 2 Maret 2020];2(1):12-21. Tersedia pada:

http://psr.ui.ac.id/index.php/journal/ar ticle/view/3380 